\title{
USE OF 35\% HYDROGEN PEROXIDE IN TOOTH BLEACHING IN DIFFERENT CLINICAL TIME INTERVALS: HOW LONG DOES SENSITIVITY LAST, AND AT WHAT TIMES IS IT MORE EXACERBATED?
}

\author{
USO DO PERÓXIDO DE HIDROGÊNIO A 35\% NO CLAREAMENTO DENTAL EM \\ DIFERENTES TEMPOS CLÍNICOS: POR QUANTO TEMPO PERDURA A \\ SENSIBILIDADE E EM QUAIS MOMENTOS ELA É MAIS EXACERBADA?
}

\author{
Elizandra Silva da PENHA ${ }^{1}$; Evalena Lima CABRAL ${ }^{2}$; Tamara da Silva GAMA ${ }^{2}$; \\ Cicera Alane de OLIVEIRA ${ }^{2}$; Ana Karina Almeida ROLIM ${ }^{1}$; Rogério Lacerda SANTOS \\ 1. Universidade Federal de Campina Grande, UFCG, Patos, PB, Brasil; 2. Cirurgiã-dentista; 3. Universidade Federal de Juiz de Fora, \\ UFJF, Governador Valadares, MG, Brasil. elizandrapenha@ hotmail.com
}

\begin{abstract}
Tooth color is one of the characteristics that define a smile as attractive, and Dentistry offers tooth whitening as an option for achieving this purpose. However, this therapy is almost always accompanied by an inconvenience: dentin sensitivity. The objective of this study was to analyze two $35 \%$ hydrogen peroxide-based materials, used in different clinical time intervals to evaluate not only the efficacy of color change, but also how long dentin sensitivity lasts, and at what times is it most exacerbated. A total of 24 volunteers were selected. The maxillary arch was divided at the midline, forming the Right Group (RG) composed of the right maxillary hemi-arch (tooth 11-15) and Left Group (LG) composed of the left maxillary hemi-arch (tooth 21-25). The mandibular arch formed the control group CG. The RG received 35\% hydrogen peroxide - Whiteness HP® - FGM Produtos Odontológicos, Joinville, SC, Brazil in three sessions of 45 minutes each ( Material 1) and LG received 35\% hydrogen peroxide - Pola Office ${ }^{\circledR}$ - SDI Limited, Bayswater, VIC, Australia in three sessions of 24 minutes each (Material 2) with an interval of one week between sessions. Color was evaluated visually by means of the Vitapan Classical Scale (Vita Zahnfabrick, Bad Säckingen, BW, Germany) at the beginning and end of each session, and 12 days after the last session. There was no statistically significant difference $(\mathrm{p}<0.05)$ in relation to bleaching potential, and intensity of sensitivity when the two materials used were compared, except in the second $(\mathrm{T}=0 \mathrm{~h})(\mathrm{P}=0.047)$ and third sessions $(\mathrm{T}=12 \mathrm{~h})(\mathrm{P}=0.033)$ in which Material 2 demonstrated a lower level of sensitivity compared with that of Material 1. Relative to the duration of sensitivity, this gradually diminished over the course of time, not exceeding 48 hours $(\mathrm{P}=1.000)$. There was no difference between the products with respect to bleaching power, and hydrogen peroxide used for a shorter time generated less tooth sensitivity.
\end{abstract}

KEY WORDS: Dental Bleaching. Tooth sensitivity. Pigmentation.

\section{INTRODUCTION}

The media and means of communication in general have aroused a greater concern about appearance in people, so that the quest for a perfect image has become a maxim of society (MARTIN et al., 2007). Enhancing the smile by means of esthetic procedures has become a great demand in dentistry, since physical appearance plays an important role in social relations, particularly in view of the new patterns of beauty, in which white, aligned teeth have a highly relevant role (WATTS; ADDY, 2001; SULIEMAN, 2000)

Dental bleaching is one of the most appreciated and sought-after procedures by patients who seek a more attractive smile. Historically, this esthetic procedure has been applied routinely in patients since the 1970s. (BUCHALLA; ATTIN, 2007). It is an efficient conservative option, compared with invasive procedures such as restorations with resin composite, facets/laminated veneers, or crowns (CARDOSO et al., 2010).
The mechanism of action of bleaching agents occurs by means of the permeable morphological characteristic of the tooth structure, and by the capacity of fluoride for diffusing through this structure due to its low molecular weight (ARAUJO et al., 2010). The free radicals generated by the breakdown of peroxide degrade the organic structure of dentin, and results in its whitening (PAULA et al., 2015).

Factors such as the concentration of the gel, capacity for attaining the long molecular chains and breaking them down, quantity and duration of applications have a direct influence on the degree of whitening (JOINER, 2006). Dental bleaching is at present the least aggressive treatment for changes in color of an extrinsic nature, and is performed with the use of carbamide and hydrogen peroxides, when vital teeth are treated.

Bleaching treatment may be performed by means of the following modalities: in-office bleaching, home bleaching, and association of the dental-office and home techniques. The in-office 
bleaching technique recommends the use of high concentrations of peroxide and promotes greater control of treatment and effectiveness of results (MONDELLI et al., 2012). The main advantage of this treatment technique is the possibility of dispensing with the use of the tray, causing the patient less discomfort. The home bleaching technique is performed by patients themselves, with the application of low concentrations of peroxide- or carbamide peroxide bleaches on the teeth by patients themselves, with the aid of customized silicone trays (CARDOSO et al., 2010).

Although considered a simple and efficient technique, there is constant discussion about the deleterious factors that bleaching may cause. Studies have shown that the procedure is safe, in spite of the undesirable effects that may occur, such as in increase in surface roughness, appearance of cracks and changes in the enamel, in addition to the degradation or change in color of existent restorations (KISHI et al., 2011; CLIFTON e CAREY, 2014; SANTANA et al., 2014)

Clinical trials have related risks relative to sensitivity, ranging from $60-90 \%$, during and after in-office dental bleaching, with this being the main adverse effect related to the bleaching procedure (PAULA et al., 2015; PAULA et al., 2013). Hydrogen peroxide and its derivatives are capable of diffusing through the hard dental tissues and reaching the dental pulp (TRINDADE et al., 2009; COSTA et al., 2010); the presence of these components in the pulp tissue result in oxidative reactions with the release of chemical mediators such as triphosphate and adenosine, which excite the pulp nociceptors (COSTA et al., 2010). These reactions clinically result in tooth sensitivity and, although it resolves on completion of treatment, it is sometimes responsible for the patient's withdrawal from treatment. The knowledge of the period when sensitivity is most exacerbated becomes of significant importance for both the professional and the patient, may guide therapeutic measures that will contribute to the success of treatment (PAULA et al., 2015).

The manner of evaluating sensitivity is considerably subjective; and there are various studies that have sought to diagnose it (BONAFÉ et al., 2013; VANO et al., 2015; REZENDE et al., 2015; KOSE et al., 2016). However, the majority of these evaluations have been performed immediately after bleaching therapy, and since sensitivity is an adverse effect that accompanies the majority of patients when they leave the dental office, studies are necessary that seek to evaluate how long the sensitivity lasts, and at what times it is most exacerbated.

The prior application of fluoride-based desensitizing agents and potassium nitrate before dental bleaching has demonstrated promising results in reducing dental sensitivity (LEONARD et al., 2007; ARMÊNIO et al., 2008; TAY et al., 2009). Another endeavor to reduce sensitivity without increasing the clinical time was the addition of some desensitizing agents to bleaching gels (MATIS et al., 2007; GALLO et al., 2009).

On the dental market, various materials are available for dental bleaching. The literature has shown that the majority of the researches conducted have compared the bleaching techniques and their side effects (MONDELLI et al., 2012; AL QURAN et al., 2011; ALMEIDA et al., 2012; BORGES et al., 2015). There are not many studies that have compared the efficacy and comfort offered by different products and substances, a fact that leads to the clinician experiencing a certain uneasiness at the time of opting for one of the bleaching systems.

In view of the foregoing, it has become necessary to verify the possible differences between these products, particularly with respect to the bleaching potential, and occurrence of sensitivity. The objective of this study was to analyze two 35\% hydrogen peroxide-based materials, used in different clinical time intervals to evaluate not only the efficacy of color change, but also how long dentin sensitivity lasts, and at what times is it most exacerbated, starting with the null hypothesis that these materials offer the same bleaching potential, without difference in the degree of sensitivity they cause.

\section{MATERIAL AND METHODS}

This study was submitted for approval, to the ethics committee on research with human beings of the Secretary for Health of the State of ParaibaSES-PB (CAAE: 33011314400005186). This was a quantitative clinical experimental research, with a cross-sectional design, of the split-mouth type, conducted and the Dental School-Clinic of the Federal University of Campina Grande - PB.

According to the inclusion criteria for the research, volunteers were selected who were in good oral and general health conditions, aged between 18 and 30 years, with the six maxillary anterior teeth and premolars, all caries-free, that presented color of the maxillary central incisor corresponding to shade A2 of the Vitapan Classical Scale (Vita Zahnfabrik, Bad Säckingen, BW, Germany), or darker. In the case of female volunteers, the 
participants had to provide a declaration that they were not pregnant or breastfeeding, and that they agreed to participate in the research by means of signing the Term of Free and Informed Consent.

No volunteers were selected, whose maxillary anterior teeth and premolars presented severe internal discoloration, endodontic treatment, periodontal treatment, extensive restorations, caries lesions, fractures, or if they had prostheses, bruxism, recessions, exposed dentin, abfraction, crowding, diastemas, open or cross bite and sensitivity to cold drinks. Also excluded were patients who had used in-office or home bleaching substances in the past year (not including tooth paste, dental floss and whitening mouth washes); who had a history of known reaction to peroxide; were taking medications, or related individual or family history of neoplasias in the oropharyngeal and adjacent regions.

Box 1. Composition of the bleaching gels

\begin{tabular}{|l|l|}
\hline \multicolumn{1}{|c|}{ MATERIAL } & \multicolumn{1}{|c|}{ COMPOSITION } \\
\hline $\begin{array}{l}\text { Material 1- Whiteness HP® FGM Produtos } \\
\text { Odontológicos, Joinville, SC, Brazil }\end{array}$ & $\begin{array}{l}35 \% \text { hydrogen peroxide, water, thickener, } \\
\text { coloring agent and glycol. }\end{array}$ \\
\hline $\begin{array}{l}\text { Material 2 - Pola office }{ }^{\circ} \text { SDI Limited, } \\
\text { Bayswater, VIC, Australia. }\end{array}$ & $\begin{array}{l}35 \% \text { hydrogen peroxide, water, thickener, } \\
\text { pigment, catalyzer and potassium nitrate- } \\
\text { based desensitizing agent. }\end{array}$ \\
\hline
\end{tabular}

Box 2. Clinical Dental Bleaching Protocol adopted in RG.

\section{PROTOCOL}

- Prophylaxis with rubber cup and Pumice Stone Paste (Maquira Dental Products, Maringá, PR, Brazil- Lot 788312)

- Color evaluation with the Vitapan Classical Scale (Vita Zahnfabrik, Bad Säckingen, BW, Germany)

- Application of Desensitizing agent Dessensibilize KF 2\% (FGM Produtos Odontológicos, Joinville, SC, Brazil - Lot: 281215), for 10 minutes;

- Soft tissue protection with gingival barrier Top Dam, (FGM Produtos Odontológicos, Joinville, SC, Brazil -Lot: 180316) in accordance with the manufacturer's recommendation;

- Manipulation of Material 1- Whiteness HP® FGM Produtos Odontológicos, Joinville, SC, Brazil - Lot: 231015), 6 drops of hydrogen peroxide to 2 drops of thickener. Application of bleaching gel on vestibular surface of teeth. The product was kept in place for 15 minutes, in accordance with the manufacturer's recommendations.

- Aspiration of gel with a surgical suction device, cleaning the teeth with gauze.

- Two more applications were made (for equal lengths of time) and at the end of the last application, the gel was aspirated, and teeth washed and afterwards polished with Diamond AC I paste (FGM, Joinville, SC/Brazil - Lot 170812) and felt disc at low speed.

- Application of neutral fluoride (Maquira Dental Products, Maringá, PR, Brazil - Lot: 308414), for 4 minutes. 
Box 3. Clinical Dental Bleaching Protocol adopted in LG.

\begin{tabular}{|c|}
\hline $\begin{array}{c}\text { PROTOCOL } \\
\text { Pronblaxis with rubher }\end{array}$ \\
\hline $\begin{array}{l}\text { Prophylaxis with rubber cup and Pumice Stone Paste (Maquira Dental Products, Maringá, } \\
\text { PR, Brazil- Lot 788312) } \\
\text { - Color evaluation with the Vitapan Classical Scale (Vita Zahnfabrik, Bad Säckingen, BW, } \\
\text { Germany) } \\
\text { Note: No desensitizer was applied, because the manufacturer did not recommend it; } \\
\text { - Soft tissue protection with gingival barrier Top Dam, (FGM Produtos Odontológicos, } \\
\text { Joinville, SC, Brazil -Lot: 180316) in accordance with the manufacturer's recommendation; } \\
\text { Manipulation of Material 2- Pola Office® (SDI Limited, Bayswater, Vic, Australia - Lot: } \\
\text { 1075074), } 6 \text { drops of hydrogen peroxide to } 1 \text { measure of thickener. Application of bleaching gel on } \\
\text { vestibular surface of teeth. The product was kept in place for } 8 \text { minutes, in accordance with the } \\
\text { manufacturer's recommendations. } \\
\text { - Aspiration of gel with a surgical suction device, cleaning the teeth with gauze. } \\
\text { - Two more applications were made (for equal lengths of time) and at the end of the last } \\
\text { application, the gel was aspirated, and teeth washed and afterwards polished with Diamond AC I } \\
\text { paste (FGM, Joinvile, SC/Brazil - Lot } 1708120 \text { ) and felt disc at low speed. } \\
\text { Application of neutral fluoride (Maquira Dental Products, Maringá, PR, Brazil - Lot: } \\
\text { 308414), for } 4 \text { minutes. }\end{array}$ \\
\hline
\end{tabular}

Three sessions were performed with an interval of one week between them. Color measurement was performed by the subjective method according to the methodology adopted in the study of Bonafé et al., (2013), in which the color of teeth was measured by two previously calibrated evaluators (Kappa 0.80). The evaluation was always made in the same place, under the same lighting and at the same time of day.

The Vitapan Classical color scale (Vita Zahnfabrik, Bad Sackingen, BW, Germany) was used by attributing numerical scores ranging from 1 to 16 . The lightest color received score 1 that corresponded to shade B1 on the scale; the darkest color received score 16 that corresponded to shade $\mathrm{C} 4$ on the scale. The maxillary central incisor was taken as a reference for determining color. Color was evaluated before and after tooth bleaching sessions, and 12 days after the last session. The last color evaluation was performed by two calibrated evaluators who were blind to the product that was applied in each hemiarch.

The patient recorded the sensitivity in four time intervals, namely: (A) at the end of each session, (B) after 12 hours had elapsed, (C) 24 hours and (D) 48 hours after bleaching. The volunteers were contacted by telephone and recorded dentin sensitivity according to the sensitivity classification scale adopted in the Wong-Baker study (2001). The scale contained numbers that ranged from 0 to 10 , in which zero corresponded to the absence of painful symptoms and tent to severe painful symptoms (Figure 1).

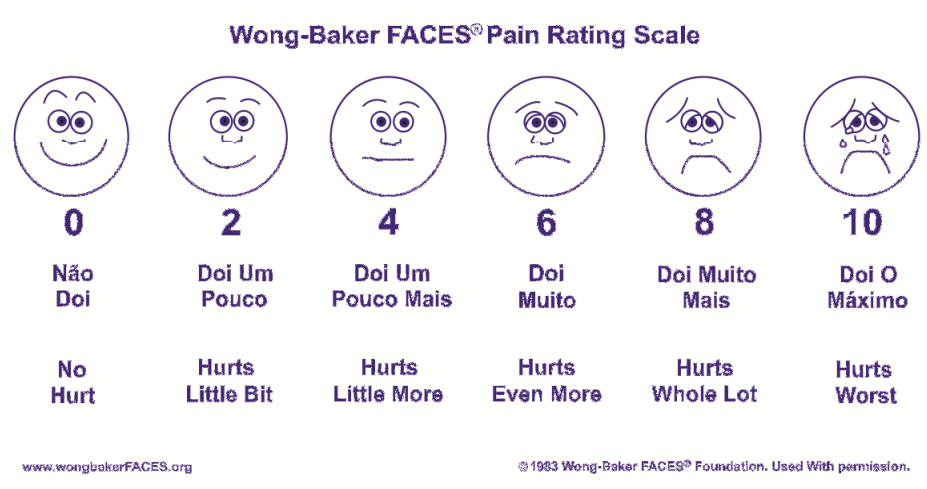

Source: WONG, 2001.

Figure 1. Wong-Baker scale of measuring sensitivity. 
For statistical analysis of color change and intensity of tooth sensitivity throughout bleaching treatment, the Kruskal-Wallis followed by the Dunn test was used. The Mann-Whitney test was used to compare the two products in relation to color change and intensity of tooth sensitivity.

\section{RESULTS}

Initial tooth color evaluation before treatment demonstrated statistically significant difference from all the other subsequent sessions, irrespective of the material used $(p<0.01)$. The greatest effect of bleaching was observed at the end of the third session, which showed statistically significant difference from the tooth color shown in the first session and beginning of the second bleaching session $(p<0.01)$ (Table 1$)$.

The Mann-Whitney test demonstrated no statistically significant difference $(p<0.05)$ in relation to bleaching potential when the two materials were compared (Table 1).

Table 1. Evaluation of tooth color among different materials and throughout the time intervals evaluated.

\begin{tabular}{|c|c|c|c|c|c|c|c|c|c|}
\hline & \multicolumn{2}{|c|}{$\begin{array}{c}1 \text { bleaching session } \\
(\mathrm{T}=0 \text { days })\end{array}$} & \multicolumn{2}{|c|}{$\begin{array}{c}2 \text { bleaching } \\
\text { sessions } \\
\text { ( } \mathrm{T}=7 \text { days }) \\
\end{array}$} & \multicolumn{2}{|c|}{$\begin{array}{c}3 \text { bleaching sessions } \\
- \\
(\mathrm{T}=\mathbf{1 4} \text { days }) \\
\end{array}$} & \multicolumn{2}{|c|}{$\begin{array}{l}12 \text { Days after } \\
\text { Final bleaching } \\
\text { ( } \mathrm{T}=\mathbf{2 6} \text { days }) \\
\end{array}$} & \multirow[t]{2}{*}{ p-Value* } \\
\hline & $\begin{array}{l}\text { Initial } \\
\text { Mean } \\
(\mathrm{SD})\end{array}$ & $\begin{array}{l}\text { Final } \\
\text { Mean } \\
(\mathrm{SD})\end{array}$ & $\begin{array}{l}\text { Initial } \\
\text { Mean } \\
(\mathrm{SD})\end{array}$ & $\begin{array}{l}\text { Final } \\
\text { Mean } \\
(\mathrm{SD})\end{array}$ & $\begin{array}{l}\text { Initial } \\
\text { Mean } \\
(\mathrm{SD})\end{array}$ & $\begin{array}{l}\text { Final } \\
\text { Mean } \\
(\mathrm{SD})\end{array}$ & $\begin{array}{l}\text { Initial } \\
\text { Mean } \\
(\mathrm{SD})\end{array}$ & $\begin{array}{l}\text { Final } \\
\text { Mean } \\
(\mathrm{SD})\end{array}$ & \\
\hline $\begin{array}{c}\text { RG } \\
\text { (Material 1) }\end{array}$ & $\begin{array}{r}6.48 \\
2.64^{\mathrm{A}}\end{array}$ & $\begin{array}{c}2.72 \\
(1.90)^{\mathrm{B}}\end{array}$ & $\begin{array}{c}2.72 \\
(1.90)^{\mathrm{B}}\end{array}$ & $\begin{array}{c}1.44 \\
(0.50)^{\mathrm{BC}}\end{array}$ & $\begin{array}{c}1.44 \\
(0.50)^{\mathrm{BC}}\end{array}$ & $\begin{array}{c}1.2 \\
(0.40)^{\mathrm{C}}\end{array}$ & $\begin{array}{c}1.44 \\
(0.58)^{\mathrm{BC}}\end{array}$ & $\begin{array}{c}1.44 \\
(0.58)^{\mathrm{BC}}\end{array}$ & $<0.001$ \\
\hline $\begin{array}{c}\text { LG: } \\
\text { (Material 2) }\end{array}$ & $\begin{array}{r}6.48 \\
2.64^{\mathrm{A}}\end{array}$ & $\begin{array}{c}2.72 \\
(1.90)^{\mathrm{B}}\end{array}$ & $\begin{array}{c}2.72 \\
(1.90)^{\mathrm{B}}\end{array}$ & $\begin{array}{c}1.44 \\
(0.50)^{\mathrm{BC}}\end{array}$ & $\begin{array}{c}1.44 \\
(0.50)^{\mathrm{BC}}\end{array}$ & $\begin{array}{c}1.2 \\
(0.40)^{\mathrm{C}}\end{array}$ & $\begin{array}{c}1.44 \\
(0.58)^{\mathrm{BC}}\end{array}$ & $\begin{array}{c}1.44 \\
(0.58)^{\mathrm{BC}}\end{array}$ & $<0.001$ \\
\hline p-Value* & 0.991 & 0.991 & 0.991 & 0.991 & 0.991 & 0.988 & 0.991 & 0.991 & ------- \\
\hline
\end{tabular}

(SD = standard deviation) A,B On line, different letters represent statistical difference by means of the Kruskal-Wallis, followed by the Dunn* test $(\mathrm{P}<0.01)$. In column, $\dagger$ Mann-Whitney Test $(\mathrm{p}<0.05)$

The intensity of dentin sensitivity gradually diminished over the course of time after each session, and did not exceed 48 hours. There was statistically significant difference between the final bleaching $(\mathrm{T}=0 \mathrm{~h})$ and after $24 \mathrm{~h}$ in the first session $(p<0.01)$; and at the end of bleaching $(\mathrm{T}=0 \mathrm{~h})$ and after $12 \mathrm{~h}$ in the subsequent sessions for Material 1 . The intensity of dentin sensitivity caused by Material 2 showed no statistically significant difference between the time intervals of evaluation, except between the final bleaching
$(\mathrm{T}=0 \mathrm{~h})$ and after $24 \mathrm{~h}$ in the third session $(p<0.01)$ (Table 2).

The Mann-Whitney test demonstrated no statistically significant difference $(p<0.05)$ in the intensity of tooth sensitivity when the two materials used were compared, except in the second $(\mathrm{T}=0 \mathrm{~h}) \quad(\mathrm{P}=0.047)$ and third session $(\mathrm{T}=12 \mathrm{~h}) \quad(\mathrm{P}=0.033) \quad$ in which Material 2 demonstrated lower capacity for generating dentin sensitivity compared with Material 1 (Table 2).

Table 2. Tooth sensitivity for different materials and throughout the time intervals evaluated

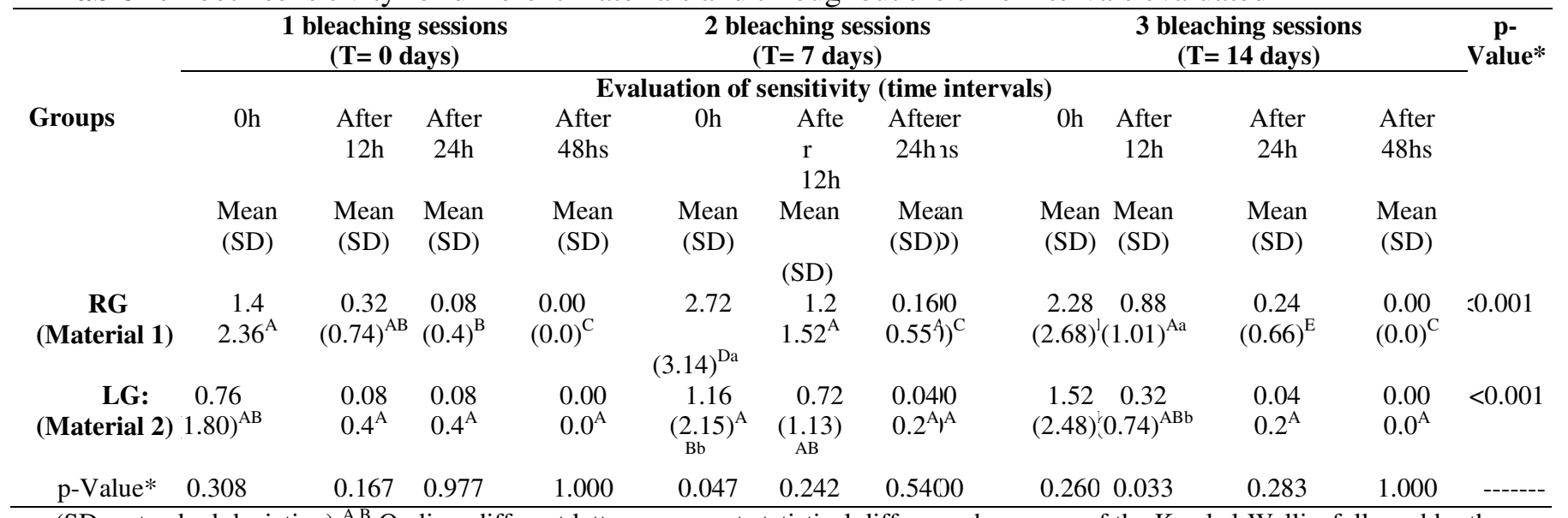

$(\mathrm{SD}=\text { standard deviation })^{\mathrm{A}, \mathrm{B}}$ On line, different letters represent statistical difference by means of the Kruskal-Wallis, followed by the Dunn* test $(\mathrm{P}<0.01){ }^{\mathrm{a}, \mathrm{b}}$ In column, different letters represent statistical difference by means of the Mann-Whitney ${ }^{\dagger}$ test $(\mathrm{p}<0.05)$. 


\section{DISCUSSION}

Various researches have evaluated the effectiveness in relation to color change, tooth sensitivity and safety of bleaching gels, by means of diverse techniques (mediate and immediate); concentrations of diverse hydrogen peroxide, carbamide peroxide, with and without sources of light activation for potentiating the bleaching gel (PAULA et al., 2015; DAWSON et al, 2011; BERGER et al, 2012; KEMALOGLU et al, 2014; HENN-DONASSOLLO et al, 2016). However, in this study, we sought to analyze two different bleaching gels with the same concentration of hydrogen peroxide, using the same bleaching technique, with the only difference being the clinical time of treatment.

For this study the experimental splitmouth design was used, which allowed the application and in vivo evaluation of the use of two bleaching gels simultaneously in the same patient, thus eliminating possible variables that could interfere in the results. In the literature, clinical studies with tooth bleaching using this type of design appear to be scarce, and the majority of them are directed towards evaluating the use of light sources, or not, during the procedure (STROBL et al, 2010).

The materials used in the research were Whiteness HP® (FGM Produtos Odontológicos, Joinville, SC, Brazil) and Pola Office ${ }^{\circledR}$ (SDILimited, Bayswater, VIC, Australia), because they had $35 \%$ hydrogen peroxide in their composition, did not require the application of light sources, had equivalent prices, and were from manufacturers whose products are commonly used in the dental office. Material 2, used in LG presented the same bleaching potential and in a shorter time of application (24 minutes per session), when compared with Material 1 used in $\mathrm{RG}$ for a time of 45 minutes per session. This fact appears to be an advantage for both the professional and patient, because it represents a shorter clinical time, providing the patient with more comfort and optimizing the dentist's work. The two brands used were shown to be effective in relation to bleaching potential, even without the use of light sources.

A similar study compared the degree of color change and tooth sensitivity of 2 in-office bleaching treatments: one with $35 \%$ hydrogen peroxide (StarBrite ${ }^{\circledR}$ ); and the other with $38 \%$ hydrogen peroxide (Opalescence Xtra Boost ${ }^{\circledR}$ ). No apparent changes in color could be perceived and there were also no significant differences between gingival irritation and tooth sensitivity between the products used (SHETHRI et al, 2003). In spite of the divergence between the form of color evaluation between the cited study and ours, the results of both showed efficacy in bleaching power, and there was no difference in color between the brands.

At present it is known that various instruments are used for measuring the change in tooth color. This includes: visual measurement by a trained clinician, and instrumental measurement using spectrophotometers, colorimeters and digital image analysis. The Vitapan Classical color scale (Vita Zahnfabrik, Bad Sackingen, BW, Germany) was one of the first methods used for this purpose. In our study, we justified its use because it is a more accessible tool, commonly used in the daily routine of dental offices and clinics. Moreover, the color perception the patient has when looking at his/her teeth in a mirror cannot be measured by technical appliances, and in this case the Vitapan color scale is one of those that most approximates the real color of the teeth. However, teeth that have received bleaching treatment may sometimes present even lighter tonalities than those offered in the color scale, and in this case, the authors suggest that further studies should be conducted using spectrophotometers, colorimeters and analysis by digital images for a more effective comparison with other researches that used these types of equipment.

In this study the degree of tooth sensitivity was evaluated by the Wong-Baker Faces Pain Rating Scale (WONG; BAKER, 2001). The results demonstrated that sensitivity varied greatly both among the patients, and in relation to the same patient during the course of the sessions, as well as between the hemiarches of each volunteer.

We analyzed the sensitivity cause by the two tooth bleaching products with $35 \%$ hydrogen peroxide both after the treatment sessions, and over the course of 12, 24 and 48 hours. We were able to perceive that the sensitivity caused by the two products tended to diminish gradually over the course of time, which may be related to the fact that the concentration of hydrogen peroxide remaining in the tooth would also be diminishing after the sessions.

The high concentration of the bleaching gel used may have contributed to the index of patients with sensitivity, during and after bleaching treatment, because if we carefully analyze the clinical studies in which the researchers used similarly used 35\% Hydrogen Peroxide gel, during in-office bleaching, we 
observed that the results demonstrated a variation between 67 and $87 \%$ in the index of patients with tooth sensitivity (MATIS et al., 2007; REIS et al, 2011).

Material 1 showed statistically significant difference between the degree of sensitivity presented by the patients over the course of time in the different sessions, while Material 2 showed no statistically significant difference between the time intervals of evaluation. Thus, we observed that after each session, the tooth became more sensitive, probably by the exposure to hydrogen peroxide in the preceding sessions; Studies have demonstrated that the concentration of the bleaching agent is directly related to the degree of sensitivity and so is the time of contact of the gel with the tooth surface (LEONARD et al, 2007; CABALLERO et al, 2006; COSTA et al, 2010). As regards tooth sensitivity when comparing the two material used, there was no statistically significant difference, except in the last two session when Material 2 demonstrated a lower capacity for generating dentin sensitivity compared with Material 1 (Table 2). This aspect draws attention due to the fact that Material2 with a shorter clinical time of application contains a desensitizing agent in its formula, while Material 1 with a longer clinical time of application, it was necessary to apply a desensitizing agent previously for 10 minutes. This leads to the hypothesis that the materials with desensitizing agents already included in their formula may present a lower capacity for generating sensitivity. Moreover, the present the same color change efficiency, a fact that needs to be proved by means of further researches with different types of products with desensitizing agents included in their formula. If proved, the use of this type of material would be an advantage to both the dentist representing a gain in time in the dental office, and to the patient, who would undergo a more rapid and less tiring session, and obtain the same end result.

The fact of having used a product that already contained a desensitizing agent in its composition, and the other in which the desensitizing agent needed to be applied before the bleaching procedure may justify the occurrence of greater or less sensitivity, making it difficult to compare the products in relation to clinical time of application. Therefore, for the purposes of research, comparing the efficacy of materials with the same substance, however, applied in different clinical times, the authors suggest that further studies must be conducted using products with different clinical times of application, but both with or without desensitizing agent included in their formula.

\section{CONCLUSION}

Material 2 showed the same bleaching potential as Material 1. In relation to sensitivity, this diminished over the course of time, and did not persist for longer than 48 hours. Material 2, caused more sensitivity in some time intervals in comparison with Material 1. In this case, the null hypothesis that these materials offered the same bleaching power, without difference in the degree of sensitivity, was discarded.

RESUMO: A cor dos dentes é uma das características que define um sorriso como atrativo e o clareamento dental uma opção oferecida pela odontologia para alcançar esse fim. Porém, essa terapia quase sempre vem acompanhada de um incomôdo; a sensibilidade dentinária. O próposito deste estudo foi analisar dois materiais a base de peróxido de hidrogênio a $35 \%$ usados em diferentes tempos clínicos avaliando, além da eficácia da cor, a sensibilidade dental, por quanto tempo perdura e em quais momentos é mais exacerbada. Selecionamos 25 voluntários, a arcada superior de cada um passou por uma divisão a partir da linha mediana, formando o grupo direito (GD) composto pela hemi-arcada superior direita (dente 11-15) e o grupo esquerdo (GE) composto pela hemi-arcada superior esquerda (dente 21-25). A arcada inferior formou o grupo controle (GC). O GD recebeu peróxido de hidrogênio a 35\% - Whiteness HP® - FGM Produtos odontológicos, Joinville, SC, Brasil em três sessões de 45 minutos cada ( Material 1) e o GE recebeu peróxido de hidrogênio a 35\% - Pola Office ${ }^{\circledR}$ - SDI Limited, Bayswater, VIC, Austrália em três sessões de 24 minutos cada ( Material 2) com intervalo de uma semana entre as sessões. A cor foi avaliada visualmente com a escala Vitapan Classical (Vita Zahnfabrick, BadSackingen, BW, Alemanha) ao iniciar e finalizar cada sessão e 12 dias após a última sessão. Não houve diferença estatística significante $(\mathrm{p}<0,05)$ em relação ao potencial clareador e nem em relação a intensidade da sensibilidade quando comparados os dois materiais utilizados, exceto na segunda $(\mathrm{T}=0 \mathrm{~h})(\mathrm{P}=0.047)$ e terceira sessão $(\mathrm{T}=12 \mathrm{~h})(\mathrm{P}=0.033)$ onde o Material 2 demonstrou menor sensibilidade comparado ao Material 1. Quanto à duração da sensibilidade, esta foi diminuindo gradativamente ao longo do tempo, não excedendo 48 horas $(\mathrm{P}=1.000)$. Não houve diferença entre os produtos no que diz respeito ao poder de clareamento e o peróxido de hidrogênio utilizado em menor tempo gerou menos sensibilidade dentária. 
PALAVRAS-CHAVES: Clareamento dental. Sensibilidade dentária. Pigmentação.

\section{REFERENCES}

ALMEIDA, L. C.; RIEHL H.; DOS SANTOS P. H.; SUNDFELD M. L.; BRISO A. L. Clinical evaluation of the effectiveness of different bleaching therapies in vital teeth. Int J Periodontics Restorative Dent, v. 32, n. 3, p. 303-309, 2012.

AL QURAN F.A.; MANSOUR Y.; AL-HYARI S.; AL WAHADNI A.; MAIR L. Efficacy and persistence of tooth bleaching using a diode laser with three different treatment regimens. Eur J Esthet Dent, v. 6, n. 4, p. 436-445, 2011.

ARAUJO F. D. E.; BARATIERI L. N.; ARAUJO E. In situ study of in-office bleaching procedures using light sources on human enamel microhardness. Oper Dent, v. 35, n. 2, p 139-146, 2010. https://doi.org/10.2341/08033-C

ARMÊNIO R. V.; FITARELLI F.; ARMÊNIO M.F.; DEMARCO F. F.; REIS A.; LOGUERCIO A. D. The effect of fluoride gel use on bleaching sensitivity. J Am Dent Assoc, v. 139, n. 5, p. 592-597, 2008.

https://doi.org/10.14219/jada.archive.2008.0220

BERGER S. B.; PAVAN S.; VIDAL C. D. M. P.; SANTOS P. H. D.; GIANNINI M.; BEDRAN-RUSSO A. K. Changes in the stiffness of demineralized dentin following application of tooth whitening agents. Acta Odontologica Scandinavica, v. 70, n. 1, p. 56-60, 2012. https://doi.org/10.3109/00016357.2011.575176

BONAFÉ E. T. R.; BACOVIS C. L.; IENSEN S.; LOGUERCIO A. D.; REIS A.; KOSSATZ S. Tooth sensitivity and efficacy of in-Office bleaching in restored teeth. Journal of Dentistry. v. 41, n. 4, p. 363-369, 2013. https://doi.org/10.1016/j.jdent.2013.01.007

BORGES A. B., ZANATTA R. F., BARROS A. C. S. M.; SILVA L. C.; PUCCI C. R.; TORRES C. R. G. Effect of Hydrogen Peroxide Concentration on Enamel Color and Microhardness. Rev. Operative Dentistry. v. 40, n. 1, p. 96-101, 2015. https://doi.org/10.2341/13-371-L

BUCHALLA W.; ATTIN, T. External bleaching therapy with activation by heat, light or laser - a systematic review. Dental Materials, v. 23, n. 5, p. 586-596, 2007. https://doi.org/10.1016/j.dental.2006.03.018

CABALLERO A. B.; NAVARRO L. F.; LORENZO J. A. At-home vital bleaching: a comparison of hydrogen peroxide and carbamide peroxide treatments. Med Oral Patol Oral Cir Bucal, v. 11, n. 1, p. E94-E9, 2006.

CARDOSO P. C.; REIS A., LOGUERCIO, A.; VIEIRA, L. C., BARATIERI L. N. Clinical effectiveness and tooth sensitivity associated with different bleaching times for a 10 percent carbamide peroxide gel. J Am Dent Assoc, v. 141, n. 10, p. 1213-1220, 2010. https://doi.org/10.14219/jada.archive.2010.0048

CLIFTON M.; CAREY B. A. Tooth whitening: what we now know. Journal of Evidence Based Dental Practice, v. 14, p. 70-76, 2014. https://doi.org/10.1016/j.jebdp.2014.02.006

COSTA C. A.; RIEHL H.; KINA J. F.; SACONO N.T.; HEBLING J. Human pulp responses to inoffice tooth bleaching. Oral Surg Oral Med Oral Pathol Oral Radiol Endod, v. 109, n. 4, p. e59-e64, 2010. https://doi.org/10.1016/j.tripleo.2009.12.002

COSTA J. B.; McPHARLIN R.; PARAVINA R. D.; FERRACANE J. L. Comparison of at-home and in-office tooth whitening using a novel shade guide. Operative dentistry, v. 35, n. 4, p. 381-388, 2010.

https://doi.org/10.2341/09-344-C 
DAWSON P. F. L.; SHARIF M. O.; SMITH A. B.; BRUNTON P.A.A. Clinical study comparing the efficacy and sensitivity of home vs combined whitening. Operative dentistry, v. 36, n. 5, p. 460-466, 2011. https://doi.org/10.2341/10-159-C

GALLO J. R., BURGESS J. O.; RIPPS A. H.; BELL M. J.; MERCANTE D. E.; DAVIDSON J. M. Evaluation of $30 \%$ carbamide peroxide at-home bleaching gels with and without potassium nitrate -a pilot study.

Quintessence Int, v. 40, n. 4, 2009.

HENN-DONASSOLLO S.; FABRIS C.; GAGIOLLA M.; KERBER Í.; CAETANO V.; CARBONI V. et al. In Situ and In Vitro Effects of Two Bleaching Treatments on Human Enamel Hardness. Brazilian dental jornal, v. 27, n. 1, p. 56-59, 2016. https://doi.org/10.1590/0103-6440201600385

JOINER A. The bleaching of teeth: a review of the literature. Journal of dentistry, v. 34, n. 7, p. 412-419, 2006. https://doi.org/10.1016/j.jdent.2006.02.002

KEMALOGLU H.; TEZEL H.; ERGÜCÜ Z. Does post-bleaching fluoridation affect the further demineralization of bleached enamel? An in vitro study. BMC oral health, v. 14, n. 1, p. 113, 2014. https://doi.org/10.1186/1472-6831-14-113

KISHI A.; OTSUKI M.; SADR A.; IKEDA M.; TAGAMI J. Effect of light units on tooth bleaching with visible-light activating titanium dioxide photocatalyst. Dental materials journal, v. 30, n. 5, p. 723-729, 2011. https://doi.org/10.4012/dmj.2010-210

KOSE C.; CALIXTO A. L.; BAUER J. R. O.; REIS A.; LOGUERCIO A. D. Comparison of the Effects of Inoffice Bleaching Times on Whitening and Tooth Sensitivity: A Single Blind, Randomized Clinical Trial. Rev. Operative Dentistry, v. 41, n. 2, p. 138-145, 2016. https://doi.org/10.2341/15-085-C

LEONARD R. H.; SMITH L. R.; GARLAND G. E.; TIWANA K. K.; ZAIDEL L. A.; PUGH G.; et al. Evaluation of side effects and patients' perceptions during tooth bleaching. Journal of Esthetic and Restorative Dentistry, v. 19, n. 6, p. 355-364, 2007. https://doi.org/10.1111/j.1708-8240.2007.00136.x

MARTIN A. J.; BUSCHANG P. H.; BOLEY J. C.; TAYLOR R. W.; McKINNEY T. W. The impact of buccal corridors on smile attractiveness. The European Journal of Orthodontics, v. 29, n. 5, p. 530-537, 2007. https://doi.org/10.1093/ejo/cjm063

MATIS B. A.; COCHRAN M. A.; ECKERT G. J.; MATIS J. I. In vivo study of two carbamide peroxide gels with different desensitizing agents. Operative Dentistry, v. 32, n. 6, p. 549-555, 2007.

https://doi.org/10.2341/07-10

MONDELLI R. F. L.; AZEVEDO J. F. D. G.; FRANCISCONI A. C.; ALMEIDA C. M. D.; ISHIKIRIAMA S.K. Comparative clinical study of the effectiveness of different dental bleaching methods - two year follow-up. Journal of Applied Oral Science, v. 20, n. 4, p. 435-443, 2012. https://doi.org/10.1590/S1678$\mathbf{7 7 5 7 2 0 1 2 0 0 0 4 0 0 0 0 8}$

PAULA E.; KOSSATZ S.; FERNANDES D.; LOGUERCIO A.; REIS A. The effect of perioperative Ibuprofen use on tooth sensitivity caused by in-office bleaching. Operative dentistry, v. 38, n. 6, p. 601-608, 2013. https://doi.org/10.2341/12-107-C

PAULA E. A.; NAVA J. A.; ROSSO C.; BENAZZI C.M; FERNANDES K. T.; KOSSATZ S., ... \& REIS A. In-office bleaching with a two-and seven-day intervals between clinical sessions: a randomized clinical trial on tooth sensitivity. J of dentistry, v. 43, n. 4, p. 424-429, 2015. https://doi.org/10.1016/j.jdent.2014.09.009 
REIS A.; DALANHOL A. P.; CUNHA T. S.; KOSSATZ S.; LOGUERCIO A. D. Assessment of tooth sensitivity using a desensitizer before light-activated bleaching. Operative dentistry, v. 36, n. 1, p. 12-17, 2011. https://doi.org/10.2341/10-148-CR

REZENDE M.; LOGUERCIO A. D.; KOSSATZ S.; REIS A. Predictive factors on the efficacy and risk/intensity of tooth sensitivity of dental bleaching: A multi regression and logistic analysis. Journal of dentistry, v. 45, p. 1-6, 2016. https://doi.org/10.1016/j.jdent.2015.11.003

SANTANA M. A. P.; NAHSAN F. P.; OLIVEIRA A. H.; LOGUÉRCIO A. D.; FARIA-E-SILVA A. L. Randomized controlled trial of sealed in-office bleaching effectiveness. Brazilian dental journal, v. 25, n. 3, p. 207-211, 2014. https://doi.org/10.1590/0103-6440201300072

SHETHRI S. A. L.; MATIS B. A.; COCHRAN M. A.; ZEKONIS R.; STROPES M. A clinical evaluarion of two in-office bleaching products. Oper Dent, v. 28, n. 5, p. 488-95, 2003.

STROBL A.; GUTKNECHT N.; FRANZEN R.; HILGERS R. D.; LAMPERT F.; MEISTER J. Laser-assisted in-office bleaching using a neodymium: yttrium-aluminum-garnet laser: an in vivo study. Lasers in medical science, v. 25, n. 4, p. 503-509, 2010. https://doi.org/10.1007/s10103-009-0675-2

SULIEMAN A. M.; An overview of tooth-bleaching techniques: chemistry, safety and efficacy. Periodontology 2000, v. 48, n. 1, p. 148-169, 2008. https://doi.org/10.1111/j.1600-0757.2008.00258.x

TAY L.Y.; KOSE C.; LOGUERCIO A. D.; REIS A. Assessing the effect of a desensitizing agent used before in-office tooth bleaching. The Journal of the American Dental Association, v. 140, n. 10, p. 1245-1251, 2009. https://doi.org/10.14219/jada.archive.2009.0047

TRINDADE F. Z.; RIBEIRO A. P.; SACONO N. T.; OLIVEIRA C. F.; LESSA F. C.; HEBLING J. et al. Transenamel and trans-dentinal cytotoxic effects of a 35\% H2O2 bleaching gel on cultured odontoblast cell lines after consecutive applications. International endodontic journal, v. 42, n. 6, p. 516-524, 2009. https://doi.org/10.1111/j.1365-2591.2009.01544.x

VANO M.; DERCHI G.; BARONE A.; GENOVESI A.; COVANI U. Tooth bleaching with hydrogen peroxide and nano-hydroxyapatite: a 9-month follow-up randomized clinical trial. International journal of dental hygiene, v. 13, n. 4, p. 301-307, 2015. https://doi.org/10.1111/idh.12123

WATTS A.; ADDY M. Tooth discoloration and staining: a review of the literature. British dental journal, v. 190, n. 6, p. 309, 2001. https://doi.org/10.1038/sj.bdj.4800959

https://doi.org/10.1038/sj.bdj.4800959a

WONG D. L.; BAKER C. M. Smiling faces for pain intensity scales. Pain, v. 89, n. 2-3, p. 295-297, 2001. https://doi.org/10.1016/S0304-3959(00)00375-4 